\title{
$\angle S$ Research Square \\ Organ/space infection is a common cause of high output stoma and outlet obstruction
}

\section{Yutaro Hara}

Department of Gastoenterological Surgery, Hirosaki University Graduate School of Medicine Takuya Miura ( $\nabla$ tmiura@hirosaki-u.ac.jp )

https://orcid.org/0000-0002-0238-2845

\section{Yoshiyuki Sakamoto}

Department of Gastroenterological Surgery, Hirosaki University Graduate School of Medicine Hajime Morohashi

Department of Gastroenterological Surgery, Hirosaki University Graduate School of Medicine.

\section{Hayato Nagase}

Department of Gastroenterological Surgery, Hirosaki University Graduate School of Medicine.

\section{Kenichi Hakamada}

Department of Gastroenterological Surgery, Hirosaki University Graduate School of Medicine

\section{Research article}

Keywords: diverting ileostomy, high-output stoma, outlet obstruction, organ/space infection

Posted Date: October 28th, 2019

DOl: https://doi.org/10.21203/rs.2.16505/v1

License: (c) (i) This work is licensed under a Creative Commons Attribution 4.0 International License. Read Full License 


\section{Abstract}

Aim: The objectives of this study are to identify causes of high-output stoma (HOS) and outlet obstruction (00), which are major complications of diverting ileostomy.

Methods: A retrospective analysis was performed in 103 patients who underwent colorectal surgery and diverting ileostomy between December 2015 and November 2018.

Results: HOS was found in 32 patients (31.1\%) and 00 in 19 (18.4\%). Organ/space surgical site infection (SSI), anastomotic leakage and 00 were independent HOS-related factors in univariate analysis, and 00 (odds ratio [OR] 3.82, $\mathrm{p}=0.022$ ) was a independent HOS-related factor in multivariate analysis.

Organ/space SSI and HOS were independent OO-related factors in univariate analysis, and organ/space SSI (OR 3.69, p=0.02) was a independent 00-related factor in multivariate analysis. The white blood cell (WBC) count on postoperative day (POD) 3 was significantly higher in the HOS group compared to the non-HOS group ( 9765 vs. $8130 / \mathrm{mL}, p<0.05)$, and the WBC count $(9400$ vs. $7475 / \mathrm{mL}, p<0.05$ ) and Creactive protein level $(6.01 \mathrm{vs} .2 .92 \mathrm{mg} / \mathrm{L}, \mathrm{p}<0.05)$ on POD 6 were significantly higher in the 00 group compared to the non-00 group.

Conclusion: Organ/space infection is involved in the common pathology of HOS and 0O. Decreased intestinal absorption due to intestinal edema caused by organ/space SSI and relative stenosis at the abdominal wall-penetrating site are major causes of $\mathrm{HOS}$ and $\mathrm{OO}$

\section{Background}

Diverting ileostomy reduces the risk of anastomotic leakage (AL) after surgery for rectal cancer, and use of diverting stoma (DS) has increased [1-3]. However, complications of ileostomy-related high output stoma (HOS) and outlet obstruction (OO) have incidences of $16-23 \%{ }^{4,5}$ and $5.6-25.8 \%[4,5]$, respectively. HOS cause dehydration, electrolyte imbalance and renal dysfunction, resulting in a significant decrease of QOL. Most studies of HOS have described detection or management, but few have examined the pathology of HOS. Causes of HOS include diabetes, total proctocolectomy, intraabdominal abscess, paralytic ileus, AL and 00, but no clear pathology has been shown [6-11]. 00 is defined as intestinal obstruction in an abdominal wall-penetrating site, but differs from general intestinal obstruction because symptoms are relieved by tube insertion from the stoma. Causes of 00 include total proctocolectomy and the thickness of the rectus abdominis muscle, but as for HOS, the pathology remains to be elucidated [12-14]. Furthermore, no study has examined HOS and 00 simultaneously and the relationship between HOS and 00 is unknown. Therefore, this study was performed as a retrospective examination of patients with DS to determine the pathology and relationship of $\mathrm{HOS}$ and $\mathrm{OO}$, and to identify related factors.

\section{Methods}


The subjects were 103 consecutive patients who underwent colorectal surgery and DS between December 2015 and November 2018. The study was performed as a retrospective analysis. The indications for DS creation were intersphincteric resection (ISR), preoperative therapy, or male patients with anastomosis just above anal canal after total mesorectal excison. Patients who underwent total proctocolectomy or emergency surgery were often considered for DS creation. The DS site was $40 \mathrm{~cm}$ distant from the terminal ileum in the right lower abdomen to penetrate the abdominal wall in the direction to allow lifting of the wall naturally. The aponeurosis of the rectus abdominis muscle was longitudinally incised with a two-finger width. A standardized technique was used to create the loop stoma.

Patient characteristics of age, sex, disease, body mass index (BMI), diabetes, smoking history, preoperative blood albumin (Alb), preoperative estimated glemerular filtration rate (eGFR) and thickness of the rectus abdominis muscle were examined. The thickness of the rectus abdominis muscle was measured using a slice at the umbilical level on CT recorded immediately before surgery. A straight line was drawn orthogonally to the horizontal axis at the maximal thickness, and the thickness of the rectus abdominis muscle was determined [13]. Surgical factors, such as operative procedure, approach, lateral lymph node dissection (LLND), operative time, blood loss volume, transfusion, intraoperative fluid, anastomotic procedure were also examined. The preoperative conditions including perforation, stenosis and preoperative chemotherapy were also examined.

Postoperative complications were analyzed using the Clavien-Dindo classification. AL was defined as clinical symptoms such as fever, abdominal pain and peritoneal irritation, and based on pus-like or stoollike output draining from the pelvic floor, anastomotic dehiscence found in a digital rectal examination, extravasation of endoluminally administered water-soluble contrast enema, and fluid or gas retention surrounding the anastomotic site detected by CT. Organ/space surgical site infection (SSI) was defined as antibiotic therapy for fever, abdominal pain and peritoneal irritation without marked findings of AL.

HOS was defined as two-days continuous output of $>1500 \mathrm{~mL}$ per day [15]. 00 was defined as symptoms of intestinal obstruction, imaging of caliber changes in the abdominal wall-penetrating site in ileostomy by $C T$, and a condition that was improved by tube retention in the oral stoma $[14,16]$. These symptoms and signs were used to confirm the diagnosis of OO. Associations of clinical factors with HOS and $0 \mathrm{O}$ were examined by Fisher chi-square test and Mann-Whitney $U$ test. Factors with a significant difference $(p<0.05)$ were then evaluated by multivariate analysis. All statistical analyses were conducted using EZR [17].

\section{Results}

Background of subjects

The median age of the 103 patients was 66 years-old and the median BMI was $22.9(16.9-38.9) \mathrm{kg} / \mathrm{m}^{2}$. Eighty two (80\%) patients were male, $16(15.5 \%)$ patients had diabetes, $26(25.2 \%)$ were smokers, and 6 $(5.8 \%)$ were being treated with steroids. Preoperatively, the Alb level was $4.2(2.4-5.0) \mathrm{g} / \mathrm{dL}$, eGFR was 
$74.9(20.1-135.2) \mathrm{mL} / \mathrm{min} / 1.73 \mathrm{~m}^{2}$, and the thickness of the rectus abdominis muscle was 10.25 (5.46$19.14) \mathrm{mm}$. The underlying diseases were malignant tumor in $84(81.2 \%)$ patients, inflammatory bowel disease in 17 (16.5\%), and perforation of colon in $2(1.9 \%)$.

Surgical procedures were low anterior resection in 52 (50.5\%) patients, intersphincteric resection in 31 (30.1\%), total proctcolectomy in $17(16.5 \%)$, and high anterior resection, sigmoidectomy and ileocecal resection in one subject each. Anastomotic procedures were a double stapling technique in 57 (55.3\%) patients and hand-sewn anastomosis in $46(44.7 \%)$. Approaches for intraperitoneal cavity used laparoscopy in 78 (75.7\%) patients, a robot-assisted method in 15 (14.6\%), and laparotomy in 10 (9.7\%). LLND was performed in 28 (27.2\%) patients and preoperative chemotherapy in 34 (33\%). The median operative time was 319 (123-639) min, median blood loss volume was 60 (0-3550) mL, median intraoperative fluid volume was $2800(419-8800) \mathrm{mL}$, and intraoperative transfusion was performed in 10 patients $(9.7 \%)$. The postoperative complications were AL in $21(20.4 \%)$ patients, organ/space SSI in 21 (20.4\%), HOS in 32 (31.1\%), and 00 in 19 (18.4\%). Grade Illb and IV complications were found in 9 patients $(8.7 \%)$, of whom 7 had AL (Table 1$)$.

Analysis of HOS

The median onset time of HOS was postoperative day (POD) 4 (range POD 2-15), the median output volume was $2460(1800-5450) \mathrm{mL}$, and the median maximum output volume on the onset day was 3005 (1800-5450) mL (Table 2). Organ/space SSI, AL, and 00 were significant HOS-related factors in univariate analysis, and $\mathrm{OO}$ (odds ratio $[\mathrm{OR}] 3.82, \mathrm{p}=0.022$ ) remained as a significantly independent factor associated with HOS in multivariate analysis (Table 3). The white blood cell (WBC) count on POD 6 was significantly higher in the HOS group than in the non-HOS group (9765 vs. $8130 / \mathrm{mL}, \mathrm{p}<0.05$ ) (Table 4). The WBC count on POD 3 and C-reactive protein (CRP) levels on PODs 3 and 6 were also higher in the HOS group.

Analysis of 00

The median onset time of $O 0$ was POD 4 (range POD 1-14), the median output volume was 1100 (25$3600) \mathrm{mL}$, and the median maximum output volume on the onset day was 2275 (80-4700) $\mathrm{mL}$ (Table 2). Organ/space SSI and HOS were significant OO-related factors in univariate analysis, but thickness of the rectus abdominis muscle did not show this relationship. Organ/space SSI (OR 3.69, P = 0.02) was a significantly independent factor associated with 00 in multivariate analysis (Table 5). The WBC count (9400 vs. $7475 / \mathrm{mL}, \mathrm{p}<0.05)$ and CRP level $(6.01$ vs. $2.92 \mathrm{mg} / \mathrm{L}, \mathrm{p}<0.05)$ on POD 6 were significantly higher in the 00 group than in the non-OO group (Table 6). The WBC count and CRP level on POD 3 were also higher in the 00 group.

\section{Discussion}

The criteria for the creation of DS vary among institutions. A meta-analysis of the significance of DS in rectal cancer showed that the anastomosis close to the anus was protected by DS [18]. A multicenter 
study in Japan showed that DS did not decrease the incidence of AL, but reduced the severity [1], and three quarters of patients with AL avoided reoperation, showing the usefulness of DS. In addition, a multicenter study confirmed that oncological safety is comparable in sphincter-preserving surgery and abdominoperineal resection of locally advanced lower rectal cancer [19]. Therefore, the DS will continue to be created in patients with rectal cancer.

Intraabdominal abscess, paralytic ileus, $\mathrm{AL}$ and $\mathrm{OO}$ have previously been identified as risk factors for HOS [6-11]. Total proctocolectomy and a history of diabetes have also been suggested to be preoperative predictors of HOS [20], but these factors were not identified as significant risk factors in this study. The reported risk factors for $\mathrm{OO}$ are total proctocolectomy and thickness of the rectus abdominis muscle at the stoma-penetrating site [12-14]. However, these factors also had no marked relationship with $\mathrm{OO}$ in this study. Infection in organ/space site was associated with the causes of HOS and OO. HOS and 00 were associated with the same factor which suggested similar pathology.

WBCs and CRP were examined on PODs 1, 3 and 6 as markers that reflect infectious conditions. The HOS and $\mathrm{OO}$ groups both had higher WBC counts and CRP levels on PODs 3 and 6 compared to the non-HOS and non-OO groups. The WBC count on POD 1 has previously been suggested to be a predictor of HOS [21], but this relationship was not significant in this study. The high WBC counts and CRP levels on PODs 3 and 6 show a prolonged postoperative infection in organ/space site, and suggest that intestinal edema and a prolonged decrease in intestinal absorption, which may be caused by infection in organ/space site, contribute to the pathology of HOS and 0O. Consequently, patients with organ/space SSI due to AL should be managed with the probability of HOS and 00 kept in mind. The median onset time of HOS and OO was POD 4, but some patients experienced HOS and OO on POD 1 and 2. Therefore, HOS and 00 may be useful for an early sign suggesting infection in organ/space site or AL.

In terms of output volume of 00 , many patients had output volume $>1000 \mathrm{~mL}$ on the day of clinical diagnosis of 00 . It may be because of prompt tube insertion in the stoma for patients with symptoms such as abdominal distension. In this study, all subjects who developed 00 were fully improved by conservative treatment such as tube insertion in the oral stoma. Therefore, the 00 pathology is relative stenosis of an abdominal wall-penetrating site of a stoma due to intestinal edema caused by organ/site $\mathrm{SSI}$. Thus, $\mathrm{OO}$ should be differentiated from general structural intestinal obstruction. And it may better to say relative outlet stenosis.

The limitations of this study are its performance at a single-center study and lack of external validity. There is a possibility that 00 was a real structural obstruction leading to HOS. However, the results of the study suggest that infection in organ/space site is the major cause of HOS and OO. Consequently, the most important countermeasure for reducing $\mathrm{HOS}$ and $\mathrm{OO}$ is to decrease the incidence of AL and infection in organ/space site. Intraoperative assessment of tissue perfusion during colorectal resection using ICG [22], insertion of an anal drain to decrease pressure in the anastomosed region [23], and stabilization of procedures using robotic-assisted surgery [24-26] may potentially improve outcomes. It is critical to treat organ/space infection with consideration of the possibility of HOS and 00 onset. 


\section{Conclusions}

HOS and 00 were found in $31 \%$ and $18 \%$ of subjects who underwent colorectal surgery and DS, respectively. Infection in the organ/space was associated with the causes of HOS and OO. HOS and 00 were associated with the same factor which suggested similar pathology.

\section{Declarations}

Ethics approval and consent to participate: The protocol for this research project has been approved by a suitably constituted Ethics Committee of the institution and it conforms to the provisions of the Declaration of Helsinki. The study was approved by the Ethics Committee of our institution (2018-1131).

Consent for publication: Not applicable

Availability of data and materials: The datasets used and/or analysed during the current study are available from the corresponding author on reasonable request.

Competing interests: The authors declare that they have no competing interests

Funding: This manuscript did not receive sponsorship for publication.

Authors' contributions: YH and TM analyzed and interpreted the patient data. YS, HM and HN performed surgery and patient management. YH was a major contributor in writing the manuscript. $\mathrm{KH}$ and TM revised the manuscript. All authors given their final approval of the version to be published and agreed to be accountable for all aspects of the work in ensuring that questions related to the accuracy or integrity of any part of the work are appropriately investigated and resolved.

Acknowledgements: The authors thank Eri Matsumoto for her support of data collection.

\section{References}

1.Shiomi A, Ito M, Maeda K, Kinugasa Y, Ota M, Yamaue H et al. Effects of a diverting stoma on symptomatic anastomotic leakage after low anterior resection for rectal cancer: a propensity score matching analysis of 1,014 consecutive patients. J Am Coll Surg 2015;220:186-94.

2.Matthiessen P, Hallbook O, Rutegard J, Simert G, Sjodahl R. Defunctioning stoma reduces symptomatic anastomotic leakage after low anterior resection of the rectum for cancer: a randomized multicenter trial. Ann Surg 2007;246:207-14.

3.Huser N, Michalski CW, Erkan M, Schuster T, Rosenberg R, Kleeff J, Friess H. Systematic review and meta-analysis of the role of defunctioning stoma in low rectal cancer surgery. Ann Surg 2008;248:52-60.

4.Okada S, Hata K, Emoto S, Murono K, Kaneko M, Sasaki K et al. Elevated risk of stoma outlet obstruction following colorectal surgery in patients undergoing ileal pouch-anal anastomosis: a 
retrospective cohort study. Surgery today 2018;48:1060-7.

5.Okita Y, Araki T, Kondo S, Fujikawa H, Yoshiyama S, Hiro J et al. Clinical Characteristics of StomaRelated Obstruction after Ileal Pouch-Anal Anastomosis for Ulcerative Colitis. Journal of gastrointestinal surgery: official journal of the Society for Surgery of the Alimentary Tract 2017;21:554-9.

6.Baker ML, Williams RN, Nightingale JM. Causes and management of a high-output stoma. Colorectal disease: the official journal of the Association of Coloproctology of Great Britain and Ireland 2011;13:191-7.

7.Nightingale J, Woodward JM. Guidelines for management of patients with a short bowel. Gut 2006;55 Suppl 4:iv1-12.

8.Robertson I, Leung E, Hughes D, Spiers M, Donnelly L, Mackenzie I, Macdonald A. Prospective analysis of stoma-related complications. Colorectal disease: the official journal of the Association of Coloproctology of Great Britain and Ireland 2005;7:279-85.

9.Caricato M, Ausania F, Ripetti V, Bartolozzi F, Campoli G, Coppola R. Retrospective analysis of long-term defunctioning stoma complications after colorectal surgery. Colorectal disease: the official journal of the Association of Coloproctology of Great Britain and Ireland 2007;9:559-61.

10.Cottam J, Richards K, Hasted A, Blackman A. Results of a nationwide prospective audit of stoma complications within 3 weeks of surgery. Colorectal disease: the official journal of the Association of Coloproctology of Great Britain and Ireland 2007;9:834-8.

11.Williams RN, Hemingway D, Miller AS. Enteral Clostridium difficile, an emerging cause for high-output ileostomy. Journal of clinical pathology 2009;62:951-3.

12.Mizushima T, Kameyama H, Watanabe K, Kurachi K, Fukushima K, Nezu R, Uchino M, Sugita A, Futami $\mathrm{K}$. Risk factors of small bowel obstruction following total proctocolectomy and ileal pouch anal anastomosis with diverting loop-ileostomy for ulcerative colitis. Ann Gastroenterol Surg 2017;1:122-8.

13.Kanazawa A, Shiozawa M, Inagaki D, Sugano N, Akaike M, Imada T. A Study om Postoperative lleus n Patients with lleostomy as a Diverting Stoma after Low Anterior Resection Journal of the Japan Society of Coloproctology 2009;62:497-501.

14.Fujii T, Morita H, Sutoh T, Yajima R, Tsutsumi S, Asao T, Kuwano H. Outlet Obstruction of Temporary Loop Diverting Ileostomy. Hepatogastroenterology 2015;62:602-5.

15.Arenas Villafranca JJ, Lopez-Rodriguez C, Abiles J, Rivera R, Gandara Adan N, Utrilla Navarro P. Protocol for the detection and nutritional management of high-output stomas. Nutr J 2015;14:45.

16.Uchino M, Ikeuchi H, Bando T, Matsuoka H, Matsumoto T, Takesue Y, Tomita N. Efficacy of a Cross Incision at the Rectal Muscle Fascia and Ileostomy Rotation for Prevention of Obstruction at the Ostomy 
Site in Restorative Proctocolectomy for Ulcerative Colitis. Journal of the Japan Society of Coloproctology 2011;64:73-7.

17.Kanda Y. Investigation of the freely available easy-to-use software 'EZR' for medical statistics. Bone marrow transplantation 2013;48:452-8.

18.Tan WS, Tang CL, Shi L, Eu KW. Meta-analysis of defunctioning stomas in low anterior resection for rectal cancer. The British journal of surgery 2009;96:462-72.

19.Okamura R, Hida K, Yamaguchi T, Akagi T, Konishi T, Yamamoto M et al. Local control of sphincterpreserving procedures and abdominoperineal resection for locally advanced low rectal cancer: Propensity score matched analysis. Ann Gastroenterol Surg 2017;1:199-207.

20.Pak J, Uemura M, Fukuda Y, Miyake M, Ikeda M, Nishikawa K et al. Predictors of High-Output Stoma After Low Anterior Resection With Diverting lleostomy for Rectal Cancer. International Surgery 2018;102:313-7.

21.Fujino S, Miyoshi N, Ohue M, Takahashi Y, Yasui M, Sugimura K et al. Prediction model and treatment of high-output ileostomy in colorectal cancer surgery. Molecular and clinical oncology 2017;7:468-72.

22.Jafari MD, Wexner SD, Martz JE, McLemore EC, Margolin DA, Sherwinter DA et al. Perfusion assessment in laparoscopic left-sided/anterior resection (PILLAR II): a multi-institutional study. J Am Coll Surg 2015;220:82-92.e1.

23.Nishigori $H$, Ito $M$, Nishizawa $Y$, Nishizawa $Y$, Kobayashi A, Sugito $M$, Saito N. Effectiveness of a transanal tube for the prevention of anastomotic leakage after rectal cancer surgery. World journal of surgery 2014;38:1843-51.

24.Yamaguchi T, Kinugasa Y, Shiomi A, Tomioka H, Kagawa H, Yamakawa Y. Robotic-assisted vs. conventional laparoscopic surgery for rectal cancer: short-term outcomes at a single center. Surgery today 2016;46:957-62.

25.Matsuda C, Adachi Y. Robotic surgery for colorectal cancer. Ann Gastroenterol Surg 2017;1:75.

26.Matsuyama T, Kinugasa Y, Nakajima Y, Kojima K. Robotic-assisted surgery for rectal cancer: Current state and future perspective. Ann Gastroenterol Surg 2018;2:406-12.

\section{Tables}

Table 1. Clinicopathological characteristics of 103 patients 


\begin{tabular}{|c|c|}
\hline Variable & Value \\
\hline Age (year)* & $66(17-82)$ \\
\hline \multicolumn{2}{|l|}{ Gender, n (\%) } \\
\hline Male & $82(80)$ \\
\hline Female & $21(20)$ \\
\hline Body mass index $\left(\mathrm{kg} / \mathrm{m}^{2}\right) *$ & $22.9(16.9-38.9)$ \\
\hline Diabetes, n (\%) & $16(15.5)$ \\
\hline Smoker, n (\%) & $26(25.2)$ \\
\hline Steroid user, n (\%) & $6(5.8)$ \\
\hline Alb $(g / d L)$ & $4.2(2.4-5)$ \\
\hline eGFR $\left(\mathrm{ml} / \mathrm{min} / 1.73 \mathrm{~m}^{2}\right)$ & $74.9(20.1-135.2)$ \\
\hline Diameter of muscle (mm) & $10.25(5.46-19.14)$ \\
\hline Perforation, n (\%) & $2(1.9)$ \\
\hline Stenosis, n (\%) & $9(8.7)$ \\
\hline Preoperative chemotherapy, n (\%) & $34(33)$ \\
\hline \multicolumn{2}{|l|}{ Cause of resection, $\mathrm{n}(\%)$} \\
\hline Neoplasia & $84(81.2)$ \\
\hline Inflammatory disease & $17(16.5)$ \\
\hline Benign pathologies & $2(1.9)$ \\
\hline \multicolumn{2}{|l|}{ Type of resection, $\mathrm{n}(\%)$} \\
\hline Low anterior resection & $52(50.5)$ \\
\hline Intersphincteric resection & $31(30.1)$ \\
\hline Total proctocolectomy & $17(16.5)$ \\
\hline Others & 3 \\
\hline \multicolumn{2}{|l|}{ Approach, n (\%) } \\
\hline Laparoscope-assisted surgery & $78(75.7)$ \\
\hline Robotic surgery & $15(14.6)$ \\
\hline Open surgery & $10(9.7)$ \\
\hline Double stapling technique, n (\%) & $57(55.3)$ \\
\hline Lateral lymph node dissection, n (\%) & $28(27.2)$ \\
\hline Operation time $(\min ) *$ & $319(123-639)$ \\
\hline Blood loss $(\mathrm{ml}) *$ & $60(0-3550)$ \\
\hline Blood transfusion, n (\%) & $10(9.7)$ \\
\hline Replacement fluid volume in the operation (ml) & $2800(419-8800)$ \\
\hline Double stapling technique, $\mathrm{n}(\%)$ & $57(55.3)$ \\
\hline Preoperative chemotherapy, n (\%) & $34(33)$ \\
\hline Anastomotic leakage, n (\%) & $21(20.4)$ \\
\hline Organ/space SSI, n (\%) & 39 (37.9) \\
\hline High output stoma, n (\%) & $32(31.1)$ \\
\hline Outlet obstruction, n (\%) & $19(18.4)$ \\
\hline \multicolumn{2}{|l|}{ Complications (Clavien-Dindo), n (\%) } \\
\hline All (I-IV) & $69(67.0)$ \\
\hline $\begin{array}{l}\text { IIIa } \\
\text { IIIb }\end{array}$ & $\begin{array}{l}12(11.7) \\
3(2.9)\end{array}$ \\
\hline \multirow[t]{2}{*}{ IV } & $6(5.8)$ \\
\hline & Page 9/16 \\
\hline
\end{tabular}


* Median (range)

Table 2. Output volume about $\mathrm{OO}$ and HOS

\begin{tabular}{llll}
\hline & OO & HOS & non-OOロHOS \\
\hline $\begin{array}{l}\text { Onset POD of HOS or OO } \\
\text { median (range) }\end{array}$ & 4 & 4 & - \\
\hline $\begin{array}{l}\text { Output volume with onset day (ml) } \\
\text { median (range) }\end{array}$ & $11-14)$ & $(2-15)$ & \\
\hline Maximum volume of stoma output (ml) & $(25-3600)$ & 2460 & - \\
median (range) & $(1800-5450)$ & \\
\hline
\end{tabular}

HOS; high output stoma, OO; outlet obstruction, POD; post operative day 
Table 3. Univariate and multivariate analyses of clinicopathological variables on High output stoma 


\begin{tabular}{|c|c|c|c|c|c|c|}
\hline \multirow[t]{2}{*}{ Variables } & & \multirow[t]{2}{*}{$\mathrm{N}$} & \multicolumn{2}{|c|}{$\begin{array}{l}\text { Univariate } \\
\text { analysis }\end{array}$} & \multicolumn{2}{|c|}{ Multivariate analysis } \\
\hline & & & n (\%) & $P$ value & $\begin{array}{l}\text { Odds ratio } \\
(95 \% \mathrm{CI})\end{array}$ & $P$ value \\
\hline \multirow[t]{2}{*}{ Age } & $\geq 65$ & 40 & 15 & & & \\
\hline & $<65$ & 53 & $\begin{array}{l}(3 / .5) \\
15 \\
(28.3)\end{array}$ & 0.670 & & \\
\hline \multirow[t]{2}{*}{ Gender } & Female & 21 & $\begin{array}{l}3 \\
(14.3)\end{array}$ & & & \\
\hline & Male & 82 & $\begin{array}{l}29 \\
(35.4)\end{array}$ & 0.070 & & \\
\hline \multirow[t]{2}{*}{ BMI $\left(\mathrm{kg} / \mathrm{m}^{2}\right)$} & $<25$ & 25 & $9(36)$ & & & \\
\hline & $\geq 25$ & 78 & $\begin{array}{l}23 \\
(29.5)\end{array}$ & 0.621 & & \\
\hline \multirow[t]{2}{*}{ Diabetes } & No & 87 & $\begin{array}{l}26 \\
(29.9)\end{array}$ & & & \\
\hline & Yes & 16 & 6 (37.5) & 0.565 & & \\
\hline \multirow[t]{2}{*}{ Smoker } & No & 77 & $\begin{array}{l}21 \\
(27.3)\end{array}$ & & & \\
\hline & Yes & 25 & $10(40)$ & 0.317 & & \\
\hline \multirow[t]{2}{*}{ Steroid user } & No & 97 & $\begin{array}{l}28 \\
(28.9)\end{array}$ & & & \\
\hline & Yes & 6 & $3(50)$ & 0.073 & & \\
\hline \multirow[t]{2}{*}{ Alb } & $\geq 4.2$ & 44 & $\begin{array}{l}14 \\
(31.8)\end{array}$ & & & \\
\hline & $<4.2$ & 59 & $\begin{array}{l}18 \\
(30.5)\end{array}$ & 1 & & \\
\hline \multirow[t]{2}{*}{ eGFR } & $\geq 60$ & 91 & $\begin{array}{l}30 \\
(33.0)\end{array}$ & & & \\
\hline & $<60$ & 12 & $\begin{array}{c}2 \\
(16.7)\end{array}$ & 0.333 & & \\
\hline \multirow[t]{2}{*}{ Diameter of muscle (mm) } & $\geq 10.25$ & 42 & $\begin{array}{l}12 \\
(28.6)\end{array}$ & & & \\
\hline & $<10.25$ & 61 & $\begin{array}{l}20 \\
(32.8)\end{array}$ & 0.672 & & \\
\hline \multirow[t]{2}{*}{ Neoplasia } & No & 19 & $\begin{array}{c}9 \\
(47.4)\end{array}$ & & & \\
\hline & Yes & 84 & $\begin{array}{l}23 \\
(27.4)\end{array}$ & 0.105 & & \\
\hline \multirow[t]{2}{*}{ Perforation } & No & 101 & $\begin{array}{l}31 \\
(30.7)\end{array}$ & & & \\
\hline & Yes & 2 & $1(50)$ & 0.527 & & \\
\hline \multirow[t]{2}{*}{ Stenosis } & No & 94 & $\begin{array}{l}28 \\
(29.8)\end{array}$ & & & \\
\hline & Yes & 9 & $\begin{array}{c}4 \\
(44.4)\end{array}$ & 0.454 & & \\
\hline \multirow[t]{2}{*}{ Operation time (min) } & $\geq 319$ & 53 & $\begin{array}{l}20 \\
(37.7)\end{array}$ & & & \\
\hline & $<319$ & 50 & $12(24)$ & 0.143 & & \\
\hline Blood loss (ml) & $\geq 60$ & 50 & $19(38)$ & & & \\
\hline \multirow{2}{*}{ Total proctocolectomy } & $\begin{array}{l}<60 \\
\text { No }\end{array}$ & $\begin{array}{l}53 \\
86\end{array}$ & $\begin{array}{l}13 \\
(24.5)\end{array}$ & 0.201 & & \\
\hline & Yes & 17 & $\begin{array}{l}24 \\
(27.9) \\
8(47)\end{array}$ & 0.153 & & \\
\hline \multirow[t]{2}{*}{ LLND } & No & 75 & $24(32)$ & & & \\
\hline & Yes & 29 & $\begin{array}{l}8 \\
(27.6)\end{array}$ & 0.814 & & \\
\hline \multirow[t]{2}{*}{ Double stapling technique } & No & 43 & $\begin{array}{l}17 \\
(39.5)\end{array}$ & & & \\
\hline & Yes & 60 & $15(25)$ & 0.134 & & \\
\hline \multirow[t]{2}{*}{ Preoperative chemotherapy } & No & 69 & $\begin{array}{l}21 \\
(30.4)\end{array}$ & & & \\
\hline & Yes & 34 & $\begin{array}{l}11 \\
(32.4)\end{array}$ & 1 & & \\
\hline
\end{tabular}




\begin{tabular}{|c|c|c|c|c|c|c|c|}
\hline \multirow[t]{2}{*}{ Blood transfusion } & No & 93 & $\begin{array}{l}28 \\
(30.1)\end{array}$ & & & & \\
\hline & Yes & 10 & $4(40)$ & 0.497 & & & \\
\hline \multirow[t]{2}{*}{$\begin{array}{l}\text { Replacement fluid volume in the operation } \\
\text { (ml) }\end{array}$} & $\geq 2800$ & 53 & $\begin{array}{l}21 \\
(39.6)\end{array}$ & & & & \\
\hline & $<2800$ & 50 & $11(22)$ & 0.059 & & & \\
\hline \multirow[t]{2}{*}{ Anastomotic leakage } & No & 84 & $\begin{array}{l}22 \\
(26.2)\end{array}$ & & & & \\
\hline & Yes & 18 & $\begin{array}{l}10 \\
(55.6)\end{array}$ & 0.024 & $\begin{array}{l}2.03 \\
7.96)\end{array}$ & $(0.52-$ & 0.310 \\
\hline \multirow[t]{2}{*}{ Organ space SSI } & No & 64 & $\begin{array}{l}13 \\
(20.3)\end{array}$ & & & & \\
\hline & Yes & 39 & $\begin{array}{l}19 \\
(48.7)\end{array}$ & 0.004 & $\begin{array}{l}2.19 \\
6.98)\end{array}$ & $(0.69-$ & 0.184 \\
\hline \multirow[t]{2}{*}{$\mathrm{OO}$} & No & 84 & 21 (25) & & & & \\
\hline & Yes & 19 & $\begin{array}{l}11 \\
(57.9)\end{array}$ & 0.011 & $\begin{array}{l}3.82 \\
12.1)\end{array}$ & $(1.21-$ & 0.022 \\
\hline
\end{tabular}

BMI; body mass index, LLND; lateral lymph node dissection, SSI; surgical site infection

Table 4. 1, 3, 6 POD WBC and CRP about HOS and non-HOS

\begin{tabular}{lllllll}
\hline & WBC & & & CRP $(\mathrm{mg} / \mathrm{L})$ & \\
\hline & HOS & non-HOS & p-value & HOS & non-HOS & p-value \\
\hline 1 POD & 9670 & 10170 & 0.606 & 6.39 & 6.68 & 0.724 \\
& $(8200-11575)$ & $(8750-11568)$ & & $(4.35-10.30)$ & $(4.93-8.63)$ & \\
3 POD & 9765 & 8130 & 0.015 & 13.28 & 11.787 & 0.224 \\
& $(8058-13210)$ & $(6950-100909)$ & & $(7.60-19.50)$ & $(7.20-14.27)$ & \\
\hline 6 POD & 8085 & 7540 & 0.122 & 5.20 & 3.01 & 0.208 \\
& $(6907-9605)$ & $(6410-8725)$ & & $(1.69-10.81)$ & $(1.70-5.71)$ & \\
\hline
\end{tabular}

HOS; high output stoma, POD; post operative day, WBC; white blood cell (3300-8600), CRP; C-reactive protein (0.00-0.14) 
Table 5. Univariate and multivariate analyses of clinicopathological variables on outlet obstruction 


\begin{tabular}{|c|c|c|c|c|c|c|}
\hline \multirow[t]{2}{*}{ Variables } & & \multirow[t]{2}{*}{$\mathrm{N}$} & \multicolumn{2}{|c|}{$\begin{array}{l}\text { Univariate } \\
\text { analysis }\end{array}$} & \multicolumn{2}{|c|}{ Multivariate analysis } \\
\hline & & & n (\%) & $P$ value & $\begin{array}{l}\text { Odds ratio } \\
(95 \% \mathrm{CI})\end{array}$ & $P$ value \\
\hline Age & $\begin{array}{l}\geq 65 \\
<65\end{array}$ & $\begin{array}{l}53 \\
50\end{array}$ & $\begin{array}{l}10(18.9) \\
9(18)\end{array}$ & 1 & & \\
\hline \multirow[t]{2}{*}{ Gender } & Female & 21 & $0(0)$ & & & \\
\hline & Male & 82 & $19(23.2)$ & 0.011 & NA & \\
\hline \multirow[t]{2}{*}{ BMI $\left(\mathrm{kg} / \mathrm{m}^{2}\right)$} & $<25$ & 25 & $6(24)$ & & & \\
\hline & $\geq 25$ & 78 & $13(16.7)$ & 0.393 & & \\
\hline \multirow[t]{2}{*}{ Diabetes } & No & 87 & $15(17)$ & & & \\
\hline & Yes & 16 & $4(25)$ & 0.129 & & \\
\hline \multirow[t]{2}{*}{ Smoker } & No & 25 & $5(20)$ & & & \\
\hline & Yes & 77 & $14(18.2)$ & 1 & & \\
\hline \multirow{2}{*}{ Steroid user } & No & 97 & 18 (18.6) & & & \\
\hline & Yes & 6 & 1 (16.7) & 0.143 & & \\
\hline \multirow[t]{2}{*}{ Alb } & $\geq 4.2$ & 44 & $11(25)$ & & & \\
\hline & $<4.2$ & 59 & $8(13.6)$ & 0.199 & & \\
\hline \multirow[t]{2}{*}{ eGFR } & $\geq 60$ & 91 & 15 (16.5) & & & \\
\hline & $<60$ & 12 & $4(33.3)$ & 0.227 & & \\
\hline \multirow[t]{2}{*}{ Diameter of muscle (mm) } & $\geq 10.25$ & 42 & $8(19.0)$ & & & \\
\hline & $<10.25$ & 61 & $11(18)$ & 1 & & \\
\hline \multirow{2}{*}{ Neoplasia } & No & 19 & $3(15.8)$ & & & \\
\hline & Yes & 84 & $16(19.0)$ & 1 & & \\
\hline \multirow[t]{2}{*}{ Perforation } & No & 101 & 19 (18.9) & & & \\
\hline & Yes & 2 & $0(0)$ & 1 & & \\
\hline \multirow[t]{2}{*}{ Stenosis } & No & 94 & $16(17.0)$ & & & \\
\hline & Yes & 9 & $3(33.3)$ & 0.361 & & \\
\hline \multirow{2}{*}{ Total proctocolectomy } & No & 86 & $16(18.6)$ & & & \\
\hline & Yes & 17 & $3(17.6)$ & 1 & & \\
\hline \multirow[t]{2}{*}{ LLND } & No & 75 & $\begin{array}{l}14 \\
(1837)\end{array}$ & & & \\
\hline & Yes & 29 & $3(10.3)$ & 1 & & \\
\hline \multirow{2}{*}{ Double stapling technique } & No & 43 & $11(25.6)$ & & & \\
\hline & Yes & 60 & $8(13.3)$ & 0.129 & & \\
\hline \multirow[t]{2}{*}{ Preoperative chemotherapy } & No & 69 & $13(18.8)$ & & & \\
\hline & Yes & 34 & $6(17.6)$ & 1 & & \\
\hline \multirow[t]{2}{*}{ Operation time (min) } & $\geq 319$ & 53 & $10(18.9)$ & & & \\
\hline & $<319$ & 50 & $9(18)$ & 1 & & \\
\hline \multirow[t]{2}{*}{ Blood loss (ml) } & $\geq 60$ & 50 & $10(20)$ & & & \\
\hline & $<60$ & 53 & $9(17.0)$ & 0.801 & & \\
\hline Blood transfusion & No & 93 & $16(17.2)$ & & & \\
\hline & Yes & 10 & $3(30)$ & 0.388 & & \\
\hline $\begin{array}{l}\text { Replacement fluid volume in the operation } \\
\text { (ml) }\end{array}$ & $\geq 2800$ & 53 & $9(17.0)$ & & & \\
\hline & $<2800$ & 50 & $10(20)$ & 0.801 & & \\
\hline Anastomotic leakage & No & 84 & $14(16.7)$ & & & \\
\hline & Yes & 18 & $4(22.2)$ & 0.518 & & \\
\hline Oragan space SSI & No & 64 & $6(9.4)$ & & & \\
\hline & Yes & 39 & $13(33.3)$ & 0.004 & $\begin{array}{l}3.69 \\
11.3)\end{array}$ & 0.022 \\
\hline HOS & No & 71 & $8(11.3)$ & & & \\
\hline & Yes & 32 & $11(34.4)$ & 0.011 & $2.95(0.99-8.8)$ & 0.052 \\
\hline
\end{tabular}

BMI; body mass index, LLND; lateral lymph node dissection, SSI; surgical site infection 
Table 6. 1, 3, 6 POD WBC and CRP about OO and non-OO

\begin{tabular}{lllllll}
\hline \multicolumn{1}{c}{ WBC } & & & CRP $(\mathrm{mg} / \mathrm{L})$ & & \\
\hline & OO & non-OO & p-value & OO & non-OO & p-value \\
\hline 1 POD & 10950 & 10060 & 0.470 & 5.52 & 6.78 & 0.508 \\
& $(8835-12900)$ & $(8410-11500)$ & & $(4.20-7.91)$ & $(4.92-9.91)$ & 0.099 \\
3 POD & 10180 & 0.068 & 14.0 & 11.73 & \\
& $(7775-12690)$ & $(7195-10343)$ & & $(9.75-22.33)$ & $(7.27-15.27)$ & \\
6 POD & 9400 & 7475 & 0.031 & 6.01 & 2.92 & 0.023 \\
& $(7050-10007)$ & $(6408-8810)$ & & $(2.97-11.05)$ & $(1.50-6.49)$ & \\
\hline
\end{tabular}

OO; outlet obstruction, POD; post operative day, WBC; white blood cell (3300-8600), CRP; C-reactive protein $(0.00-0.14)$ 